\title{
BROOD PARASITISM AND NEST SURVIVAL OF BROWN-HEADED COWBIRD HOSTS AT HIGH-ELEVATION RIPARIAN SITES IN THE EASTERN SIERRA NEVADA, CALIFORNIA
}

\author{
Sacha K. Heath ${ }^{1,2}$, Leah A. Culp ${ }^{1}$, and Christine A. Howell ${ }^{1}$
}

\begin{abstract}
Deciduous riparian ecosystems in the western United States provide habitat for a higher density of breeding birds than reported for any other avian habitat type and provide habitat for more breeding bird species than adjacent uplands. On the east slope of the Sierra Nevada, riparian ecosystems make up $<1 \%$ of United States Forest Service lands yet experience a disproportionate amount of recreational use and development. Two of these developments, pack-station corrals and campgrounds, provide foraging opportunities for the Brown-headed Cowbird (Molothrus ater)—an obligate brood parasite that forages on bare ground and feedlots but typically commutes to distinct shrubland or woodland habitats for breeding. We examined nest survival, brood parasitism, breeding phenology, and causes of nest failure for birds at North Lake and Rock Creek: 2 high-elevation (>2500 m) riparian breeding habitats adjacent to recreational development and within cowbird commuting distance to additional potential foraging sites. Nest survival tended to be higher for host species at Rock Creek than for those at North Lake, but parasitism rates were not significantly different between plots. Of 21 open-cup nesting species, 12 were parasitized. We found the highest rate of parasitism (92\%) for Warbling Vireos (Vireo gilvus) at North Lake, and parasitism contributed to lower total nest survival there $(14 \%)$. For nearly all species, parasitized nests were less successful and produced fewer young than nonparasitized nests. However, predation was the leading cause of complete nest failure across all species and contributed to the lowest total nest survival estimates for Western Wood-Pewees (Contopus sordidulus, 11\%) and Dusky Flycatchers (Empidonax oberholseri, 15\%) at North Lake and for Dark-eyed Juncos (Junco hyemalis, 15\%) at Rock Creek. Nest survival was relatively high for Western Wood-Pewees (41\%) at Rock Creek and for Yellow Warblers (Dendroica petechia, 47\%) at North Lake. We noted whether the arrival of pack animals at pack-station corrals contributed to variation in cowbird numbers at corrals or in parasitism rates at the 2 sites. Cowbirds occupied corrals before and after pack-stock arrival, and most host clutches were completed prior to pack-stock arrival at nearby corrals, suggesting that the presence of pack animals did not directly affect cowbird host species.
\end{abstract}

Key words: riparian birds, Brown-headed Cowbirds, brood parasitism, nest survival, predation, Sierra Nevada, pack stations, pack stock.

Deciduous riparian ecosystems bordering streams, rivers, and mesic sites in the western United States provide habitat for a higher density of breeding birds than reported for any other avian habitat type and provide habitat for more breeding bird species than adjacent uplands (reviewed by Knopf et al. 1988, Ohmart 1994, Saab et al. 1995). Riparian ecosystems of the eastern Sierra Nevada are no exception and support diverse breeding-bird communities, including species of conservation concern (Heath and Ballard 2003, McCreedy and Heath 2004, Heath 2008). In the Sierra Nevada of California, $60 \%$ of the land is publicly owned (Duane 1999). However, the eastern and western slopes vary in degree of land development. The western slope has experienced greater pressures from land development, with 10\%-20\% of foothills converted to agriculture or human structures (George and Dobkin 2002). The eastern slope is physically isolated and has a comparatively sparse human population (Duane 1999), with $0 \%-10 \%$ of land converted to agriculture or human structures (George and Dobkin 2002).

Although the proportion of land development is minimal in the eastern Sierra Nevada, its public lands are not pristine. The Inyo National Forest (Inyo NF) manages most eastern Sierra Nevada lands above $1200 \mathrm{~m}$ in Mono and Inyo counties, and Inyo NF is one of the most visited recreational areas in the United States (1983 visits exceeded 7 million; Kondolf et al. 1987). Riparian ecosystems make up only $0.4 \%$ of Inyo NF lands yet experience heavily concentrated recreational use (Kondolf et al. 1987). Stream diversions, stream impoundments, and

${ }^{1}$ PRBO Conservation Science, 3820 Cypress Drive \# 11, Petaluma, CA 94954.

2Present address: Department of Wildlife, Humboldt State University, 1 Harpst Street, Arcata, CA 95521. E-mail: sheath@prbo.org 
livestock grazing have also heavily impacted riparian-ecosystem vegetation and hydrology (Smith et al. 1991, Stromberg and Patton 1992, Kauffman et al. 2000, Fitzhugh and Richter 2004). Paved roads accessing high-elevation areas (up to $3100 \mathrm{~m}$ ) tend to follow streams of the larger glacial drainages, and recreational developments, such as campgrounds and small resorts, are often situated in or adjacent to riparian ecosystems. Mountain pack stations are common among these riparian-situated recreational developments. Horses and mules are maintained in corrals at the pack stations and are taken for trail rides and remote backcountry excursions during summer and fall.

The presence of recreational and rural developments located among bird-rich riparian breeding habitats (Heath and Ballard 2003) likely contributed to the proliferation of the Brown-headed Cowbird (Molothrus ater) in the high eastern Sierra Nevada since the 1930s (Rothstein et al. 1980). Brown-headed Cowbirds are obligate brood parasites that lay their eggs in the nests of host species, thereby obliging hosts to raise foreign young to independence (Ortega 1998). Because cowbirds do not build nests or rear offspring, they are able to spatially and temporally separate their breeding and foraging activities (Rothstein et al. 1984, Thompson 1994). In the eastern Sierra Nevada, Rothstein et al. (1984) documented Brown-headed Cowbirds commuting up to $7 \mathrm{~km}$ between morning breeding habitats, which were predominantly streamside or meadow-forest edge habitats, and afternoon foraging sites, mostly in livestock corrals at mountain pack stations but also in campgrounds and at bird feeders. They observed 6 host species that were parasitized on the east slope: Warbling Vireos (Vireo gilvus), Yellow Warblers (Dendroica petechia), Dark-eyed Juncos (Junco hyemalis), Song Sparrows (Melospiza melodia), Green-tailed Towhees (Pipilo chlorurus), and an unidentified Empidonax sp. (Rothstein et al. $1980 ; \bar{x}=3.2$ nests per host species).

Brown-headed Cowbirds reduce the number of host-young fledglings, cause host-nest failure or abandonment, and prey on host eggs and nestlings (Ortega 1998, Lorenzana and Sealy 1999). These costs on individual hosts can have detrimental consequences to some populations of host species (e.g., Kus 1999, Whitfield and Sogge 1999), while other populations maintain stability despite parasitism pressure (e.g., Sedgwick and Iko 1999). The threshold above which parasitism becomes a limiting factor can depend on species, localized rate of parasitism, or population demographics in absence of parasitism (May and Robinson 1985, Smith 1999). For example, nest predation is the major cause of nest failure for most passerines and can impose great costs on individual nesters not affected by parasitism (Martin 1992). Moreover, habitats that support both high nest-predator and Brownheaded Cowbird densities can create a combination of predation and parasitism that greatly reduces host productivity (Tewksbury et al. 1998). Thus, it is necessary to determine both nest parasitism rates and nest predation rates in order to identify limiting factors to hosts.

Rothstein et al. (1980) suggested that the relatively recent expansion of Brown-headed Cowbirds into the Sierra Nevada could pose a threat to naïve host species, especially since cowbirds were scarce in the region prior to about 1940. Verner and Ritter (1983) also strongly recommended continued monitoring of cowbirds and their hosts in various localities in the Sierra Nevada. Herein we describe nest survival, nest parasitism, and breeding chronology for 12 Brown-headed Cowbird hosts in highelevation riparian breeding habitats of the eastern Sierra Nevada. Our objective was to assess the potential impacts of parasitism and predation on host reproduction in a high-elevation riparian habitat embedded in a landscape with multiple cowbird foraging sites. We also note the relation between parasitism rates and Brownheaded Cowbird numbers and the arrival of pack animals to the nearest pack-station corral.

\section{Methods}

Study Area

We studied 2 high-elevation riparian areas, $32 \mathrm{~km}$ apart and located on Inyo NF land in the eastern Sierra Nevada, California, during 20012004 . The sites were chosen because they provided nesting habitat for breeding bird species of Inyo NF management concern (e.g., Warbling Vireos and Yellow Warblers) and because they were near pack stations and campgrounds. The sites also were embedded in a landscape that provided multiple foraging opportunities for Brown-headed Cowbirds (Rothstein et al. 1980, 1984). The sites were representative of many of the eastward-draining, glacially carved canyons in the region, with respect to recreational development (Kondolf et al. 1987) and bird 
community composition (Heath and Ballard 2003).

The North Lake site (2840 m, Inyo County, $\left.37^{\circ} 13^{\prime} 48^{\prime \prime} \mathrm{N}, 118^{\circ} 37^{\prime} 1^{\prime \prime} \mathrm{W}\right)$ was a 21 -ha plot (n $=1$ ) that contained 2 trailhead parking lots and the North Lake Pack Station. The packstation corral kept approximately 50 mules and horses during each summer of our study. Within $10 \mathrm{~km}$ upstream from the plot were one developed campground and the John Muir Wilderness boundary; within $10 \mathrm{~km}$ downstream from the plot were a small housing development (approximately 140 homes), 8 developed campgrounds, and a side fork of the same drainage, which contained another pack station $(9 \mathrm{~km}$ away) and 2 developed campgrounds. Within a $10-\mathrm{km}$ radius of North Lake, there were 2 active grazing allotments. Cattle grazed one allotment starting on 15 June in 2001, 2003, and 2004, and 1 July in 2002. Cattle did not graze the other allotment in 2001 but started grazing on 25 June in 2002 and 2004, and the start date is unknown for 2003 (L. Murphy, Inyo NF, personal communication).

The Rock Creek site $(2600 \mathrm{~m}$, Mono County, $\left.37^{\circ} 30^{\prime} 29^{\prime \prime} \mathrm{N}, 118^{\circ} 42^{\prime} 52^{\prime \prime} \mathrm{W}\right)$ was on an 18-ha plot $(n=1)$ that contained a developed campground and a 2 -lane paved road. Within $10 \mathrm{~km}$ upstream from the plot were 7 developed campgrounds, a resort development, the Rock Creek Pack Station's lower corral (4.5 km away), and its main pack-station corral ( $7 \mathrm{~km}$ away). The lower corral retained animals en route to the main pack-station corral during heavy snow years and also retained overflow and injured animals (we observed 3-50 mules and horses there); a maximum of 110 animals were permitted for the Rock Creek Pack Station during the years of our study (M.B. Hennessy, Inyo NF, personal communication). Within $10 \mathrm{~km}$ downstream from the Rock Creek plot were 5 developed campgrounds, a small housing development (population approximately 115), and a restaurant. Within a $10-\mathrm{km}$ radius of the plot, there was one active sheep and goat allotment on Inyo NF lands as well as livestock leases on City of Los Angeles lands in the valley below; sheep and goat permits ran from 15 June to 1 October 2001 and from 20 July to 30 September during 2002-2004 (L. Murphy, Inyo NF, personal communication). Livestock typically grazed from mid- to end of May through October (D. House, Los Angeles Department of Water and Power, personal communication).
Vegetation at North Lake and Rock Creek were both characterized as aspen and subalpine/montane wetland shrub habitat series (Sawyer and Keeler-Wolf 1995). Predominant vegetation included quaking aspen (Populus tremuloides), willow shrub (Salix spp.), and sedge (Carex spp.) meadow. Absolute cover of vegetation layers was similar at Rock Creek and North Lake study plots (15\% tree, 35-40\% shrub, and 60-70\% herbaceous) (PRBO unpublished data). Both study sites were bordered by lodgepole pine forest (Pinus contorta), shrub fields (primarily Artemisia tridentata, Purshia tridentata, and Cercocarpus ledifolius), and granite talus. On-site water sources included creeks, springs, and North Lake.

\section{Field Methods}

We began territory mapping and nest searching in early May for all bird species breeding within plot boundaries. We visited each plot every $2-4$ days until breeding activity declined in early August, from 2001 to 2004. We determined territory numbers for all species by mapping cumulative observations of simultaneously singing males, counter-singing males, territorial interactions, and nests and by comparing nestcycle timing with neighboring pairs (Robbins 1970). We located nests using methods suggested by Martin and Geupel (1993). At North Lake and Rock Creek, respectively, we found active nests for $67 \%$ and $71 \%$ of Western Wood-Pewee (Contopus sordidulus) territories, $65 \%$ and $29 \%$ of Dusky Flycatcher (Empidonax oberholseri) territories, $63 \%$ and $50 \%$ of Warbling Vireo territories, $65 \%$ and $58 \%$ of Yellow Warbler territories, $42 \%$ and $25 \%$ of Yellow-rumped Warbler (Dendroica coronata) territories, 5\% and $16 \%$ of Fox Sparrow (Passerella iliaca) territories, $55 \%$ and $73 \%$ of Song Sparrow territories, $55 \%$ and $53 \%$ of Dark-eyed Junco territories, and $50 \%$ and $38 \%$ of Cassin's Finch (Carpodacus cassinii) territories. We found nests for $44 \%$ of White-crowned Sparrow (Zonotrichia leucophrys) territories at North Lake and $50 \%$ of Black-headed Grosbeak (Pheucticus melanocephalus) territories at Rock Creek. Brewer's Blackbirds (Euphagus cyanocephalus) defended territories or bred in tightly clustered colonies at both sites; we were not able to determine the percentage of pairs for which we found nests.

We followed nest-monitoring guidelines outlined by Martin and Geupel (1993). We checked 
nest contents every $1-4$ and occasionally 5 days $(\bar{x}=3.1)$ until final failure or fledging. During each check, we observed nest contents and recorded number of host and cowbird eggs or young. To view contents of high nests, we used extension poles fitted with Mini CCD Color Pinhole Cameras (Swann Communications USA Inc., Santa Fe Springs, CA) or we climbed trees. In cases where nests were too high for either method, we determined nest stage by noting adult or nestling behavior (e.g., adult incubating, turning eggs, or feeding young; or young visible over nest edge) (Martin and Geupel 1993). We were not able to determine parasitism status for these nests unless cowbird young were visible from below. After nestcycle completion, we made follow-up visits to confirm presence or absence of fledglings and considered a nest successful if $\geq 1$ host young fledged.

We conducted cowbird counts on average every $7.5 \pm 1.6$ (mean \pm SD) days at the North Lake corral and Rock Creek overflow corral from mid-May through July or the first week of August, from 2001 to 2004 . We did not conduct counts at the Rock Creek Pack Station itself since snowpack made it inaccessible for most of the bird breeding season in some years. Despite previous reports that cowbird breeding and foraging activity are split temporally and spatially between morning breeding habitats and afternoon foraging habitats (Rothstein et al. 1984), we conducted cowbird counts twice each day (the first between 06:00 and 09:00 and the other typically between 12:00 and 16:00). Counts were at least one hour apart and spanned 5 minutes; we recorded number of cowbirds, distance to each individual ( $\leq 50 \mathrm{~m}$ or $>50 \mathrm{~m})$, sex, and age (adult or juvenile). Counts were done from the same central location of each corral, within a 50-m-radius circle which encompassed the entire corral. Each year, we performed, on average, $5.50 \pm 1.73$ near-weekly counts prior to pack-stock arrival and $5.25 \pm 0.96$ after packstock arrival at North Lake and $4.75 \pm 1.26$ before and $5.75 \pm 0.50$ after at Rock Creek.

Data Summary and Analysis

For all species parasitized by Brown-headed Cowbirds at North Lake and Rock Creek, we calculated the proportion of nests parasitized for (1) all species combined by plot and year and for (2) each species by plot with all years combined. We derived these summaries using all nests observed with $\geq 1$ host or cowbird egg or young, for which we observed the entire nest contents. In addition, we calculated the proportions of nonparasitized and parasitized nests that were successful. We derived these summaries using nests observed with $\geq 1$ host or cowbird egg or young, for which we observed the entire nest contents and determined the outcome. We defined a successful nest as one in which at least one host young fledged. We calculated the mean numbers of host young fledged from nonparasitized and parasitized nests that we observed with $\geq 1$ host egg or young and for which we observed all nestlings within 4 days of fledge date.

For each species, we also estimated daily nest survival (DNS; Mayfield 1975, Johnson 1979) and total nest survival (the probability of a nest surviving the entire length of the nest period $=$ DNSnest period length) by plot, all years combined. We derived these estimates from all nests observed with $\geq 1$ host egg or young. Hensler and Nichols (1981) and Nur et al. (1999) advise against comparing estimates of DNS for studies with $\leq 20$ nests per species or treatment. We did not meet this criterion for all species at both locations. We nonetheless deemed our results for all parasitized species instructive and worth reporting, but our estimates derived from low samples must be interpreted with caution.

For nests with known fates, DNS exposure period was terminated midway between the last day of observed host activity and the first day of observed host inactivity. For nests with unknown fates $(<2.5 \%)$, we terminated exposure period on the last day of observed host activity (Manolis et al. 2000). Exposure periods were terminated on the predicted hatch day for parasitized and nonparasitized nests with unhatched host eggs. To calculate total nest survival we used the following nest period lengths (laying + incubation + nestling, in days): Yellow Warbler $=23.1$ and Song Sparrow $=25$ (Mono County PRBO unpublished data); Western Wood-Pewee $=32.8$, Dusky Flycatcher $=34.7$, Warbling Vireo $=29$, Yellow-rumped Warbler $=28$, Black-headed Grosbeak $=27$, Whitecrowned Sparrow $=25$, Fox Sparrow $=25.25$, Dark-eyed Junco $=27.5$, Brewer's Blackbird $=29$, and Cassin's Finch $=31.5$ (Sedgwick 1993, Chilton et al. 1995, Hill 1995, Hahn 1996, Hunt and Flaspohler 1998, Bemis and Rising 1999, Gardali and Ballard 2000, Martin 2002, Nolan et al. 2002, Weckstein et al. 2002). 
TABLE 1. Percentage of nests parasitized by Brown-headed Cowbirds (\% parasitized) for all nests ${ }^{\mathrm{a}}(n)$, proportion of successful nests $\left(\%\right.$ successful $=$ fledged at least one host young) for nonparasitized and parasitized nests ${ }^{b}(n)$, and mean number of host young fledged per nest ${ }^{\mathrm{c}}$ for nonparasitized and parasitized nests at North Lake and Rock Creek, eastern Sierra Nevada, California, 2001-2004.

\begin{tabular}{|c|c|c|c|c|c|c|}
\hline \multirow[b]{2}{*}{ Species } & \multirow[b]{2}{*}{ Location } & \multirow[b]{2}{*}{$\begin{array}{c}\% \text { Parasitized } \\
(n)\end{array}$} & \multicolumn{2}{|c|}{$\%$ Successful $(n)$} & \multicolumn{2}{|c|}{ Number fledged per nest } \\
\hline & & & $\begin{array}{c}\text { Non- } \\
\text { parasitized }\end{array}$ & Parasitized & $\begin{array}{c}\text { Non- } \\
\text { parasitized }\end{array}$ & Parasitized \\
\hline Western Wood-Pewee & $\begin{array}{l}\text { North Lake } \\
\text { Rock Creek }\end{array}$ & $\begin{array}{r}8(13) \\
14(21)\end{array}$ & $\begin{array}{r}9(11) \\
63(19)\end{array}$ & $\begin{array}{l}0(1) \\
0(3)\end{array}$ & $\begin{array}{l}0.3 \\
1.1\end{array}$ & $\begin{array}{l}0 \\
0.3\end{array}$ \\
\hline Dusky Flycatcher & $\begin{array}{l}\text { North Lake } \\
\text { Rock Creek }\end{array}$ & $\begin{array}{l}37(41) \\
50(8)\end{array}$ & $\begin{array}{l}* 42(24) \\
100(4)\end{array}$ & $\begin{array}{l}7(15) \\
0(2)\end{array}$ & $\begin{array}{l}1.3 \\
2.8\end{array}$ & $\begin{array}{l}0.5 \\
0\end{array}$ \\
\hline Warbling Vireo & $\begin{array}{l}\text { North Lake } \\
\text { Rock Creek }\end{array}$ & $\begin{array}{l}* * 92(13) \\
43(28)\end{array}$ & $\begin{array}{l}100(1) \\
60(15)\end{array}$ & $\begin{array}{r}0(10) \\
30(10)\end{array}$ & $\begin{array}{l}0.8 \\
1.1\end{array}$ & $\begin{array}{l}0 \\
0.3\end{array}$ \\
\hline Yellow Warbler & $\begin{array}{l}\text { North Lake } \\
\text { Rock Creek }\end{array}$ & $\begin{array}{l}23(39) \\
29(7)\end{array}$ & $\begin{array}{l}63(30) \\
80(5)\end{array}$ & $\begin{array}{r}38(8) \\
0(2)\end{array}$ & $\begin{array}{l}1.8 \\
2.8\end{array}$ & $\begin{array}{l}0.7 \\
0\end{array}$ \\
\hline Yellow-rumped Warbler & $\begin{array}{l}\text { North Lake } \\
\text { Rock Creek }\end{array}$ & $\begin{array}{l}50(2) \\
50(2)\end{array}$ & $\begin{array}{l}0(1) \\
0(1)\end{array}$ & $\begin{array}{r}100(1) \\
0(1)\end{array}$ & $\begin{array}{l}0 \\
0\end{array}$ & $\begin{array}{l}1.0 \\
0\end{array}$ \\
\hline Black-headed Grosbeak & Rock Creek & $100(1)$ & $(0)$ & $0(1)$ & 0 & 0 \\
\hline White-crowned Sparrow & North Lake & $50(4)$ & $50(2)$ & $50(2)$ & 2.0 & 1.0 \\
\hline Fox Sparrow & $\begin{array}{l}\text { North Lake } \\
\text { Rock Creek }\end{array}$ & $\begin{array}{r}100(1) \\
50(4)\end{array}$ & $\begin{array}{r}(0) \\
50(2)\end{array}$ & $\begin{array}{l}0(1) \\
0(2)\end{array}$ & $\begin{array}{l}0 \\
1.0\end{array}$ & $\begin{array}{l}0 \\
0\end{array}$ \\
\hline Song Sparrow & $\begin{array}{l}\text { North Lake } \\
\text { Rock Creek }\end{array}$ & $\begin{array}{l}53(17) \\
55(11)\end{array}$ & $\begin{array}{r}71(7) \\
100(5)\end{array}$ & $\begin{array}{l}43(7) \\
50(6)\end{array}$ & $\begin{array}{l}2.4 \\
3.4\end{array}$ & $\begin{array}{l}0.7 \\
0.8\end{array}$ \\
\hline Dark-eyed Junco & $\begin{array}{l}\text { North Lake } \\
\text { Rock Creek }\end{array}$ & $\begin{array}{l}50(4) \\
13(16)\end{array}$ & $\begin{array}{c}0(1) \\
50(14)\end{array}$ & $\begin{array}{l}0(2) \\
0(2)\end{array}$ & $\begin{array}{l}0 \\
1.4\end{array}$ & $\begin{array}{l}0 \\
0\end{array}$ \\
\hline Brewer's Blackbird & $\begin{array}{l}\text { North Lake } \\
\text { Rock Creek }\end{array}$ & $\begin{array}{l}17(36) \\
10(20)\end{array}$ & $\begin{array}{l}38(29) \\
61(18)\end{array}$ & $\begin{array}{r}17(6) \\
0(2)\end{array}$ & $\begin{array}{l}1.2 \\
2.1\end{array}$ & $\begin{array}{l}0.5 \\
0\end{array}$ \\
\hline Cassin’s Finch & $\begin{array}{l}\text { North Lake } \\
\text { Rock Creek }\end{array}$ & $\begin{array}{l}13(8) \\
25(4)\end{array}$ & $\begin{array}{l}57(7) \\
50(2)\end{array}$ & $\begin{array}{r}(0) \\
0(1)\end{array}$ & $\begin{array}{l}1.4 \\
1.5\end{array}$ & $\begin{array}{l}0 \\
0\end{array}$ \\
\hline
\end{tabular}

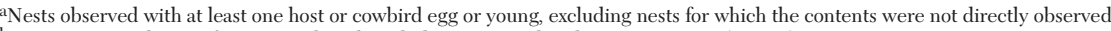

bSame nest sample as in footnote $a$, though excluding nests with unknown outcomes $(<2.5 \%)$.

cAll nest attempts observed with at least 1 host egg or young and for which entire brood was observed within 4 days of fledge date.

$* P<0.05$, between parasitism status, for a given species and location.

$* * P<0.001$, between plots, for a given species.

We determined the proportions of nest failure due to predation (previously active nests that were empty prior to expected fledge date or for which a direct predation event was observed), parasitism (only cowbird young fledged), desertion (dead nestlings, unhatched eggs after expected hatch date, or absence of parents), and weather (desertion following multiple days of extreme weather). Since identification of nest predators or determination of precise cause of nest failure can be unreliable without the use of recording devices (Lariviére 1999, Liebezeit and George 2003, Thompson and Burhans 2003), we did not attempt to assign specific predators to predation events. Thus, nest failures that we attributed to predation likely included predation by cowbirds and could also have included nests that were predated following desertion.

Female Brown-headed Cowbirds lay most eggs in host nests before host-clutch completion and onset of incubation (Lowther 1993); therefore, we calculated the proportion of total nests with clutch-completion dates before and after pack-stock arrival for each plot and year. For both corrals during each year, we used adult cowbird counts within $50 \mathrm{~m}$ of count stations to compare morning and afternoon counts of both female and male cowbirds. We used the maximum number of female and male cowbirds from either the morning or afternoon counts per count day to compare the following for each corral and year: (1) percentage of visits in which we observed cowbirds at corrals before and after pack-stock arrival, and (2) numbers of female and male cowbirds before and after pack-stock arrival.

We tested for differences in nest proportions using Fisher's exact test and tested for differences in cowbird counts using Wilcoxon's signed-rank tests in program $\mathrm{R}$ version 2.9.1 (R Development Core Team 2008). We tested for differences in daily nest survival using CONTRAST (Hines and Sauer 1989, Nur et 
TABLE 2. Arrival date of pack stock at North Lake and Rock Creek corrals, percent of host nest clutches completed prior to pack-stock arrival (nest cc), and total percent of nests parasitized by Brown-headed Cowbirds by year, eastern Sierra Nevada, California, 2001-2004.

\begin{tabular}{|c|c|c|c|c|c|c|}
\hline & \multicolumn{3}{|c|}{ North Lake } & \multicolumn{3}{|c|}{ Rock Creek } \\
\hline & Pack stock & Nest cca & Nests parasitized $^{b}$ & Pack stock & Nest cc ${ }^{\mathrm{a}}$ & Nests parasitized ${ }^{b}$ \\
\hline 2001 & 21 June & $82 \%$ & $31 \%$ & 22 June & $84 \%$ & $30 \%$ \\
\hline 2002 & 1 July & $86 \%$ & $33 \%$ & 18 June & $* 50 \%$ & $34 \%$ \\
\hline 2003 & 4 July & $81 \%$ & $31 \%$ & 19 June & $69 \%$ & $33 \%$ \\
\hline 2004 & 2 July & $81 \%$ & $42 \%$ & 28 June & $81 \%$ & $17 \%$ \\
\hline
\end{tabular}

aTotal number of host nests for which host clutch completion date was determined (in chronological order): $n=34,57,69,27$ at North Lake; $n=19,30,59,27$ at Rock Creek.

${ }^{b}$ Host nests observed with at least 1 host or cowbird egg or young, excluding nests for which the contents were not directly observed (in chronological order): $n=$ $36,51,65,26$ at North Lake; $n=20,23,54,24$ at Rock Creek.

$* P<0.05$, difference among years.

al. 1999). Significance was assumed at $\alpha=0.05$. Data are presented as means with standard deviations, unless otherwise noted.

\section{Results}

Twenty-five and 31 bird species held territories or bred at North Lake and Rock Creek plots, respectively (Appendix). We found 351 nests for 23 species at North Lake and 268 nests for 26 species at Rock Creek. Besides Black-headed Grosbeaks, which bred only at Rock Creek, and White-crowned Sparrows, which bred only at North Lake, 10 species were parasitized by Brown-headed Cowbirds at both sites: Western Wood-Pewee, Dusky Flycatcher, Warbling Vireo, Yellow Warbler, Yellow-rumped Warbler, Fox Sparrow, Song Sparrow, Dark-eyed Junco, Brewer's Blackbird, and Cassin's Finch (Table 1).

Of all the species with $n \geq 5$ nests at North Lake and Rock Creek, Dusky Flycatchers, Warbling Vireos, and Song Sparrows had $>35 \%$ of their nests parasitized (Table 1). Warbling Vireos at North Lake had the highest parasitism rate, with $92 \%$ of 13 nests parasitized (plot difference, $P=0.005$ ). Parasitism rates were not significantly different between plots for any other species $(P \geq 0.16)$; total parasitism rates for all host species combined at North Lake and at Rock Creek were $33 \%(n=178)$ and $31 \%(n=$ 121), respectively. Total parasitism rates for all species combined were not significantly different between years at North Lake $(P=0.75)$ or at Rock Creek $(P=0.47$; Table 2$)$. In nearly every species and plot combination, parasitized nests were less successful and produced fewer young than nonparasitized nests (Table 1). This difference was significant only for Dusky Flycatchers at North Lake $(P=0.02$, all others $P$ $\geq 0.07$ ). Dusky Flycatchers, Warbling Vireos,
Yellow Warblers, Yellow-rumped Warblers, White-crowned Sparrows, Song Sparrows, and Brewer's Blackbirds all successfully fledged both cowbird and natal young at least once, whereas Western Wood-Pewees, Black-headed Grosbeaks, Fox Sparrows, Dark-eyed Juncos, and Cassin's Finches did not fledge natal young from parasitized nests.

Of the species with $n \geq 15$ nests at North Lake, 4 species had total nest survival below $20 \%$. Of species with $n \geq 15$ nests at Rock Creek, 2 species had total nest survival exceeding 35\% (Table 3). Differences in DNS between plots were significant only for Western Wood-Pewees $\left(\chi^{2}=7.6, \mathrm{df}=1, P=0.03\right)$ and Dusky Flycatchers $\left(\chi^{2}=4.5, \mathrm{df}=1, P=\right.$ $0.006)$. Predation (including potential predation by cowbirds) accounted for most nest failures for every species except the White-crowned Sparrow (Table 3). Cases where only cowbird young fledged accounted for $46 \%$ of Warbling Vireo nest failure at North Lake and $50 \%$ of Dusky Flycatcher nest failure at Rock Creek. Of the 8 deserted nests, 2 nests (1 Yellow Warbler, 1 Brewer's Blackbird) contained cowbird eggs or young.

Brown-headed Cowbird timing and numbers varied across years and plots, but female and male cowbirds were present at corrals well before pack-stock arrived in all years except 2002, when only males were observed at North Lake (Fig. 1). Cowbird numbers during morning (AM) versus afternoon (PM) counts were not significantly different for males or females in any year at North Lake $(P \geq 0.16)$ and were significantly different at Rock Creek only for females in 2003 (AM count: $1.13 \pm 1.61$; PM count: $2.09 \pm 1.81$; $P=0.013$ ) and for males in 2002 (AM count: $0.46 \pm 1.20$; PM count: $0.15 \pm 0.38 ; P=0.046$ ) Mean maximum number of female cowbirds 
TABLE 3. Daily nest survival (DNS) with standard errors (SE), total nest survival, and proportional causes of nest failure (predation, fledged only cowbirds, desertion of egg or young, weather) for species parasitized by Brown-headed Cowbirds at North Lake and Rock Creek, eastern Sierra Nevada, California, 2001-2004

\begin{tabular}{|c|c|c|c|c|c|c|c|c|}
\hline \multirow[b]{2}{*}{ Species } & \multirow[b]{2}{*}{ Location } & \multirow[b]{2}{*}{$n^{\mathrm{a}}$} & \multirow[b]{2}{*}{ DNS (SE) } & \multirow[b]{2}{*}{ Total $(\%)$} & \multicolumn{4}{|c|}{$\begin{array}{c}\text { Cause of nest failure } \\
\text { (\% of failed nests) }\end{array}$} \\
\hline & & & & & Pred. & Cow. & Des. & Wea. \\
\hline Western Wood-Pewee* & $\begin{array}{l}\text { North Lake } \\
\text { Rock Creek }\end{array}$ & $\begin{array}{l}18 \\
24\end{array}$ & $\begin{array}{l}0.935(0.016) \\
0.973(0.008)\end{array}$ & $\begin{array}{l}11 \\
41\end{array}$ & $\begin{array}{l}93 \\
91\end{array}$ & $\begin{array}{l}0 \\
9\end{array}$ & $\begin{array}{l}0 \\
0\end{array}$ & $\begin{array}{l}7 \\
0\end{array}$ \\
\hline Dusky Flycatcher** & $\begin{array}{l}\text { North Lake } \\
\text { Rock Creek }\end{array}$ & $\begin{array}{r}40 \\
7\end{array}$ & $\begin{array}{l}0.947(0.010) \\
0.986(0.010)\end{array}$ & $\begin{array}{l}15 \\
62\end{array}$ & $\begin{array}{l}89 \\
50\end{array}$ & $\begin{array}{r}7 \\
50\end{array}$ & $\begin{array}{l}0 \\
0\end{array}$ & $\begin{array}{l}4 \\
0\end{array}$ \\
\hline Warbling Vireo & $\begin{array}{l}\text { North Lake } \\
\text { Rock Creek }\end{array}$ & $\begin{array}{l}16 \\
34\end{array}$ & $\begin{array}{l}0.934(0.018) \\
0.966(0.008)\end{array}$ & $\begin{array}{l}14 \\
36\end{array}$ & $\begin{array}{l}54 \\
89\end{array}$ & $\begin{array}{l}46 \\
11\end{array}$ & $\begin{array}{l}0 \\
0\end{array}$ & $\begin{array}{l}0 \\
0\end{array}$ \\
\hline Yellow Warbler & $\begin{array}{l}\text { North Lake } \\
\text { Rock Creek }\end{array}$ & $\begin{array}{r}35 \\
8\end{array}$ & $\begin{array}{l}0.968(0.008) \\
0.970(0.017)\end{array}$ & $\begin{array}{l}47 \\
50\end{array}$ & $\begin{array}{l}76 \\
67\end{array}$ & $\begin{array}{r}7 \\
33\end{array}$ & $\begin{array}{r}14 \\
0\end{array}$ & $\begin{array}{l}0 \\
0\end{array}$ \\
\hline Yellow-rumped Warbler & $\begin{array}{l}\text { North Lake } \\
\text { Rock Creek }\end{array}$ & $\begin{array}{l}2 \\
3\end{array}$ & $\begin{array}{l}0.980(0.020) \\
0.902(0.066)\end{array}$ & $\begin{array}{r}56 \\
6\end{array}$ & $\begin{array}{l}100 \\
100\end{array}$ & $\begin{array}{l}0 \\
0\end{array}$ & $\begin{array}{l}0 \\
0\end{array}$ & $\begin{array}{l}0 \\
0\end{array}$ \\
\hline Black-headed Grosbeak & Rock Creek & 2 & $0.889(0.074)$ & 3 & 100 & 0 & 0 & 0 \\
\hline White-crowned Sparrow & North Lake & 4 & $0.902(0.066)$ & 8 & 0 & 50 & 50 & 0 \\
\hline Fox Sparrow & $\begin{array}{l}\text { North Lake } \\
\text { Rock Creek }\end{array}$ & $\begin{array}{l}1 \\
4\end{array}$ & $\begin{array}{l}0.818(0.164) \\
0.932(0.038)\end{array}$ & $\begin{array}{r}1 \\
17\end{array}$ & $\begin{array}{r}100 \\
67\end{array}$ & $\begin{array}{r}0 \\
33\end{array}$ & $\begin{array}{l}0 \\
0\end{array}$ & $\begin{array}{l}0 \\
0\end{array}$ \\
\hline Song Sparrow & $\begin{array}{l}\text { North Lake } \\
\text { Rock Creek }\end{array}$ & $\begin{array}{l}16 \\
10\end{array}$ & $\begin{array}{l}0.951(0.017) \\
0.984(0.011)\end{array}$ & $\begin{array}{l}28 \\
66\end{array}$ & $\begin{array}{r}63 \\
100\end{array}$ & $\begin{array}{r}25 \\
0\end{array}$ & $\begin{array}{l}0 \\
0\end{array}$ & $\begin{array}{r}13 \\
0\end{array}$ \\
\hline Dark-eyed Junco & $\begin{array}{l}\text { North Lake } \\
\text { Rock Creek }\end{array}$ & $\begin{array}{r}4 \\
16\end{array}$ & $\begin{array}{l}0.692(0.128) \\
0.933(0.022)\end{array}$ & $\begin{array}{r}0 \\
15\end{array}$ & $\begin{array}{r}75 \\
100\end{array}$ & $\begin{array}{l}0 \\
0\end{array}$ & $\begin{array}{l}0 \\
0\end{array}$ & $\begin{array}{r}25 \\
0\end{array}$ \\
\hline Brewer's Blackbird & $\begin{array}{l}\text { North Lake } \\
\text { Rock Creek }\end{array}$ & $\begin{array}{l}35 \\
20\end{array}$ & $\begin{array}{l}0.944(0.011) \\
0.955(0.014)\end{array}$ & $\begin{array}{l}19 \\
29\end{array}$ & $\begin{array}{l}75 \\
90\end{array}$ & $\begin{array}{l}8 \\
0\end{array}$ & $\begin{array}{r}13 \\
0\end{array}$ & $\begin{array}{r}4 \\
10\end{array}$ \\
\hline Cassin’s Finch & $\begin{array}{l}\text { North Lake } \\
\text { Rock Creek }\end{array}$ & $\begin{array}{r}12 \\
5\end{array}$ & $\begin{array}{l}0.975(0.011) \\
0.968(0.018)\end{array}$ & $\begin{array}{l}45 \\
36\end{array}$ & $\begin{array}{r}80 \\
100\end{array}$ & $\begin{array}{l}0 \\
0\end{array}$ & $\begin{array}{r}20 \\
0\end{array}$ & $\begin{array}{l}0 \\
0\end{array}$ \\
\hline
\end{tabular}

Active nests in which host eggs or young observed, unknown outcomes included.

$* P<0.05$, DNS between plots.

$* * P<0.01$, DNS between plots.

per count day per year was $0.70 \pm 1.05$ at North Lake (range 0-3) and $1.34 \pm 1.31$ at Rock Creek (range 0-5). Mean maximum number of male cowbirds was $1.37 \pm 1.41$ at North Lake (range 0-6) and $1.57 \pm 1.91$ at Rock Creek (range 0-8).

Pack-stock arrival dates varied across years by up to 8 days at the North Lake corral and by up to 10 days at the Rock Creek overflow corral (Table 2). Across years, we observed Brownheaded Cowbirds at corrals during $61 \% \pm 39 \%$ of counts before and $67 \% \pm 3 \%$ of counts after pack-stock arrival at North Lake, and during $83 \% \pm 14 \%$ of counts before and $83 \% \pm 24 \%$ of counts after pack-stock arrival at Rock Creek (Fig. 1). Mean maximum numbers of female or male cowbirds before versus after pack-stock arrival were not significantly different at North Lake (females, $P=0.09$; males, $P=0.09$ ) or Rock Creek (females, $P=0.47$; males, $P=0.58$ ).

The period of host species clutch-completion dates ranged from 21 May \pm 4.2 days to 23 July \pm 6.8 days at North Lake and from 23 May \pm
4.5 days to 19 July \pm 4.1 days at Rock Creek, during 2001-2004. During all years at North Lake and during 3 years at Rock Creek, most host clutches were complete prior to pack-stock arrival, regardless of stock arrival date, and parasitism rates were similar between years $(P=$ 0.75 ; Table 2). The only significant exception was at Rock Creek in 2002, when 50\% of clutches were completed after the earliest pack-stock arrival date (difference among years, $P=0.03$ ); but parasitism was not exceedingly high in that year (difference among years, $P=0.47$ ).

\section{Discussion}

\section{Parasitism}

Twelve of 21 open-cup nesting species at North Lake and Rock Creek were parasitized by Brown-headed Cowbirds (Appendix). We documented parasitism in 5 of 6 species reported in the eastern Sierra Nevada by Rothstein et al. (1980): Empidonax flycatcher (Dusky Flycatchers, in our case), Warbling Vireo, Yellow 

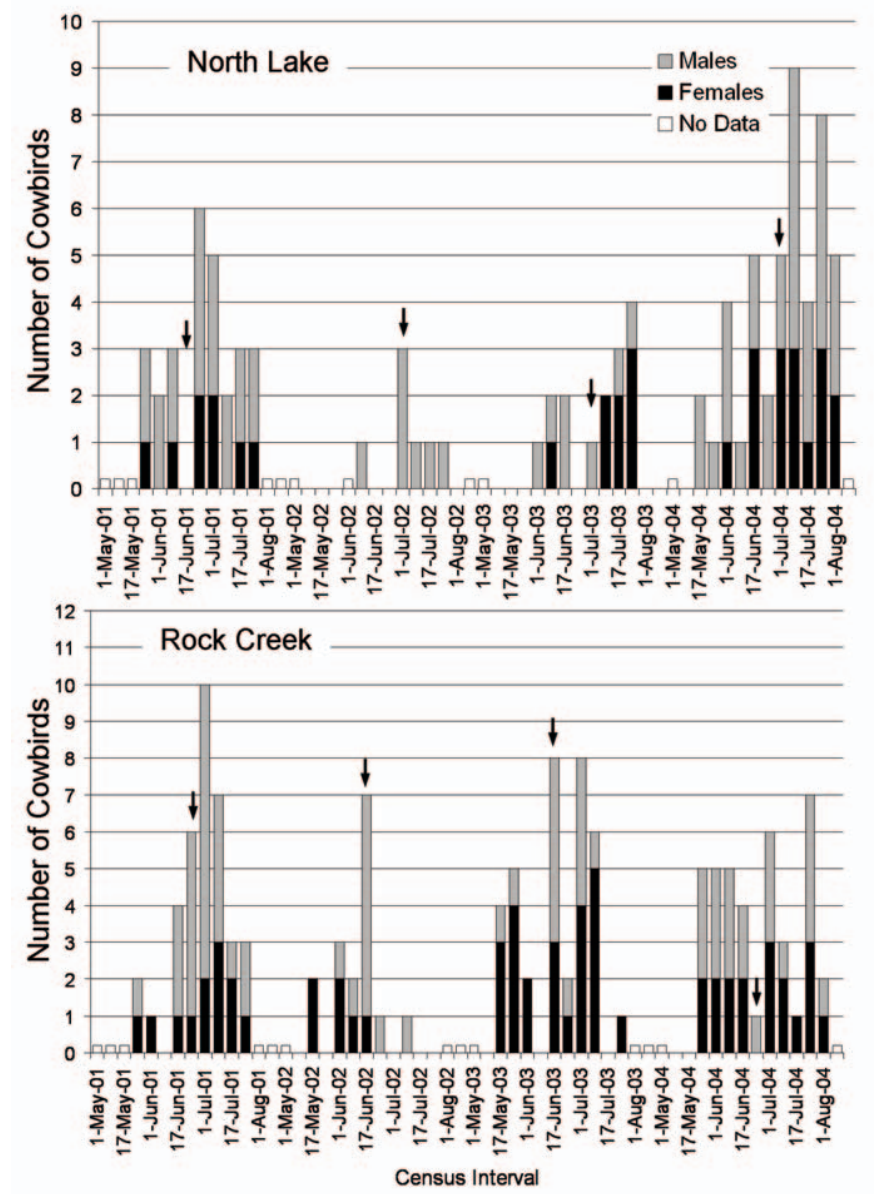

Fig. 1. Maximum number of male and female cowbirds observed during each count day within census interval (first date of interval is labeled) at the North Lake Pack Station corral and Rock Creek Pack Station overflow corral. Intervals having no data bars were those in which counts were not performed. Arrows indicate the period in which pack animals were first observed at the pack station each year in eastern Sierra Nevada, California, 2001-2004.

Warbler, Dark-eyed Junco, and Song Sparrow. The exception was the Green-tailed Towhee, which did not breed on the North Lake or Rock Creek study plots, though we have documented parasitism for this species elsewhere in the eastern Sierra Nevada (e.g., Heath et al. 2006). Western Wood-Pewees, Brewer's Blackbirds, and Fox Sparrows were parasitized on our study sites but not at other east-slope locations studied by Rothstein et al. (1980) in the late 1970s. Indeed, Rothstein et al. (1980) found it "perplexing" that none of the Brewer's Blackbird nests they found were parasitized at their mountain sites; nearly 30 years later, $17 \%$ and $10 \%$ of this species' nests were parasitized at $\geq 2600$ $\mathrm{m}$ (Table 1). Species for which we documented parasitism but for which Rothstein et al. (1980) did not find nests in the eastern Sierra Nevada were Yellow-rumped Warblers, Black-headed Grosbeaks, White-crowned Sparrows, and Cassin's Finches (Table 1).

Brown-headed Cowbird parasitism incurred costs on individual host reproduction at these high-elevation riparian sites. For nearly every species, lower proportions of nests were successful and fewer young were produced in parasitized than in nonparasitized nests (Table 1). However, only Warbling Vireos at North Lake had an extremely high parasitism rate (92\%) coupled with a high proportion of failed nests fledging only cowbirds $(46 \%)$ and low total nest survival $(14 \%$; Tables 1,3$)$. Such a low total 
nest survival is of concern since it is likely lower than necessary for a population to maintain viability (approximately 35\% for a generalized neotropical migrant with 2 nesting attempts per season and given $60 \%$ adult and $30 \%$ juvenile survival; Donovan and Thompson 2001). Purcell (2006) suggested that lower nest survival estimates $(30 \%-32 \%)$ in the western Sierra Nevada indicated inability of Warbling Vireo populations to self-sustain given published survival rates; low productivity has also been linked to Warbling Vireo population declines elsewhere in California (Gardali et al. 2000).

Though parasitism was clearly responsible for low Warbling Vireo nest survival at North Lake, other factors also contributed to poor vireo nest survival at other locations. Nest-survival estimates for Warbling Vireos at lower eastern Sierra Nevada elevations (1800 m) were also depressed (10\%, $n=20$, Gardali and Ballard 2000 ), where $21 \%$ of the nests fledged only cowbirds and $67 \%$ failed due to predation $(n=24$, PRBO unpublished data). Rock Creek nest-survival estimates were moderate by comparison (36\%), where $42 \%$ of the nests were parasitized and $89 \%$ failed due to predation. At other Sierra Nevada locations, nest survival was closer to our Rock Creek estimate (northern Sierra Nevada $30 \%$ - Smith et al. 2005; west slope 30\%-60\%Purcell 2006), but parasitism rates were much lower $7 \%$ in northern Sierra Nevada-Smith et al. 2005; 7\% on west slope-Purcell 2006). Our Warbling Vireo nest survival rates were lower than those reported for Great Basin aspen and willow sites in eastern Oregon, where major anthropogenic influences (agriculture, grazing, human habitation) were reported absent (55\%-Heltzel and Earnst 2006); however, parasitism was similar (47\%-Heltzel and Earnst 2006).

\section{Predation}

Predation (which could include cowbird predation) also had an impact on host reproduction. Even for species with high parasitism rates (Song Sparrows: 53\% at North Lake and 55\% at Rock Creek; Dusky Flycatchers: 37\% at North Lake; Warbling Vireos: $43 \%$ at Rock Creek), predation accounted for the majority of nest failures (Song Sparrows: 63\% at North Lake and $100 \%$ at Rock Creek; Dusky Flycatchers: 89\%; Warbling Vireos: 89\%). Predation coincided with comparatively low nest survival for Song Sparrows (28\%) and very low nest survival for Dusky
Flycatchers $(15 \%)$ at North Lake. Western Wood-Pewees had low rates of parasitism at North Lake $(8 \%)$ but very low total nest survival (11\%), mostly due to predation (93\%). Only $17 \%$ (North Lake) and 10\% (Rock Creek) of Brewer's blackbird nests were parasitized, but predation accounted for $75 \%$ and $90 \%$ of nest failures, respectively; and nest survival was low (19\% and $29 \%$, respectively). Finally, only $13 \%$ of Darkeyed Junco nests were parasitized at Rock Creek, but nest survival was low (15\%) and predation accounted for $100 \%$ of nest failures.

We directly observed only one predation event (Steller's Jay [Cyanocitta stelleri] removing nestlings from a Western Wood-Pewee nest at Rock Creek) and otherwise identified only potential predators via anecdotal observations and daily tallies. Thus, further study is needed to attribute observed nest-predation patterns to specific predator assemblages found on our study plots. Of the potential nest-predator species we observed at Rock Creek and North Lake, 8 have been observed as nest predators of this study's host species in other eastern and north central Sierra Nevada studies. At 3000-m subalpine meadow sites north of our study area in Mono County, Morton et al. (1993) attributed White-crowned Sparrow nest-predation rates $(29.9 \%, n=1132)$ primarily to Belding's ground squirrels (Spermophilus beldingi); they also observed nest predation by Clark's Nutcrackers (Nucifraga columbiana), Cassin's Finches, and Douglas's squirrels (Tamiasciurus douglasii). In the north central Sierra Nevada, Cain et al. (2003) found that Yellow Warbler nest survival was negatively associated with activity indices of Douglas's squirrels, Steller's Jays, and Brown-headed Cowbirds and that predation accounted for $93 \%$ of nest failures. Also in Mono County, at lower-elevation (2000-m) riparian tributaries of Mono Lake, video cameras placed at Yellow Warbler and Song Sparrow nests recorded predation events by 4 species we observed at North Lake or Rock Creek: deer mouse (Peromyscus spp.), Steller's Jay, weasel (Mustela spp.), and Brown-headed Cowbird (Latif 2009).

\section{Highest Nest-Survival Estimates}

The highest nest-survival estimates for species with $n \geq 15$ nests were $47 \%$ for Yellow Warblers at North Lake and $41 \%$ for Western Wood-Pewees at Rock Creek. Yellow Warblers at North Lake successfully fledged their own 
young from $38 \%$ of parasitized nests. This was also the case at lower elevations northeast of our site at Mono Lake, Mono County, where Yellow Warbler young fledged from $36 \%$ of parasitized nests $(n=412$; Heath 2008). Our estimates of Yellow Warbler nest survival were similar to what Cain et al. (2003) found in willow meadows of their north central Sierra Nevada study site $(52 \%)$ and were higher than at Mono Lake $(34 \% \pm 8 \%, n=646 ; 2001-$ 2004 PRBO unpublished data) or in eastern Oregon (33\%; Heltzel and Earnst 2006). The Yellow Warbler is a California bird species of special concern whose population size and range in California has declined primarily because of riparian habitat loss (Heath 2008). Wet high-elevation willow meadows are valuable for Yellow Warbler reproduction in the Sierra Nevada (Cain et al. 2003, this study), and maintaining their quality as breeding habitat will be important for the conservation of this species.

\section{Pack Stations}

Our plots were embedded in a landscape that provided multiple foraging sites within cowbird commuting distance. We were unable to differentiate between parasitism from cowbirds utilizing pack stations and parasitism from cowbirds using other foraging opportunities, yet we found no evidence that pack-stock arrival increased parasitism rates at our site. We detected no female cowbirds within $50 \mathrm{~m}$ of North Lake corrals in 2002, yet the percentage of parasitized nests was not lower at North Lake in 2002 than in other years (Fig. 1, Table 2). With the exception of Warbling Vireos, which had detrimental parasitism rates at North Lake $(92 \%)$, there was no uniform difference in parasitism rates between North Lake and Rock Creek study plots, even though the nearest packstock corral was within the study plot at North Lake and $4.5 \mathrm{~km}$ from the Rock Creek study plot. Most host clutches were completed before pack-stock arrival, and accordingly most parasitism occurred before pack-stock arrival (79\% at North Lake; 75\% at Rock Creek). In 2002, when significantly fewer Rock Creek clutches were completed prior to pack-animal arrival than in other years, parasitism did not increase significantly (Table 2).

We observed cowbirds at the North Lake and Rock Creek corrals whether or not pack animals were present (Fig. 1). Brown-headed
Cowbirds are typically attracted to corrals because of the feed, manure, and horseflies (Tabanus spp.) associated with the livestock (Rothstein et al. 1984, 1987); and pack stations are typically cleaned of manure and feed at the end of each season (G. Milano, Inyo NF, personal communication). For these reasons, we expected to observe more cowbirds at corrals after pack-animal arrival (as demonstrated by Rothstein et al. 1987), yet this was not the case. Lack of nearby late-season hosts was probably not an explanation; even in 2003 at North Lake, when pack animals did not arrive until 4 July, hosts continued to complete clutches until 20 July. It is likely that cowbirds were attracted to the corrals themselves prior to animal arrival and that cowbird counts remained similarly low throughout the season.

\section{ACKNOWLEDGMENTS}

U.S. Forest Service Region 5 Partners in Flight and Inyo NF provided financial support; we thank Gary Milano in particular. A grant from Carolyn Johnson and Rick Theis supported the preparation of this manuscript. We thank field biologists Tia Adams, Noah Hamm, and Brian Scavone for mapping territories and finding and monitoring nests, and we also thank Chris McCreedy and Grant Ballard for their assistance. Mike Morrison and an anonymous reviewer greatly improved the manuscript. Portions of this manuscript were written at the Palomarin Field Station, which received support from NSF (DBI-0533918). This is PRBO Contribution Number 1724.

\section{Literature Cited}

Bemis, C., AND J.D. Rising. 1999. Western Wood-Pewee (Contopus sordidulus). Issue No. 451 in A. Poole, editor, The Birds of North America Online. Cornell Lab of Ornithology, Ithaca, NY. Available from: http:// bna.birds.cornell.edu/bna

Cain, J.W., M.L. Morrison, and H.L. Bombay. 2003. Predator activity and nest success of Willow Flycatchers and Yellow Warblers. Journal of Wildlife Management 67:600-610.

Chilton, G., M.C. Baker, C.D. Barrentine, and M.A. Cunningham. 1995. White-crowned Sparrow (Zonotrichia leucophrys). Issue No. 183 in A. Poole, editor, The Birds of North America Online. Cornell Lab of Ornithology, Ithaca, NY. Available from: http://bna birds.cornell.edu/bna

Donovan, T.M., AND F.R. Thompson III. 2001. Modeling the ecological trap hypothesis: a habitat and demographic analysis for migratory songbirds. Ecological Applications 11:871-882. 
DuAnE, T.P. 1999. Shaping the Sierra: nature, culture, and conflict in the changing West. University of California Press, Berkeley, CA. 595 pp.

Fitzhugh, T.W., AND B.D. Richter. 2004. Quenching urban thirst: growing cities and their impacts on freshwater ecosystems. BioScience 54:741-754.

Gardali, T., AND G. BaLLaRd. 2000. Warbling Vireo (Vireo gilvus). Issue No. 214 in A. Poole, editor, The Birds of North America Online. Cornell Lab of Ornithology, Ithaca, NY. Available from: http://bna.birds .cornell.edu/bna

Gardali, T., G. Ballard, N. Nur, and G.R. Geupel. 2000. Demography of a declining population of Warbling Vireos in coastal California. Condor 102:601-609.

GEORGE, T.L., AND D.S. DoBKIN. 2002. Introduction: habitat fragmentation and western birds. Studies in Avian Biology 25:4-7.

Hahn, T. 1996. Cassin's Finch (Carpodacus cassinii). Issue No. 240 in A. Poole, editor, The Birds of North America Online. Cornell Lab of Ornithology, Ithaca, NY. Available from: http://bna.birds.cornell.edu/bna

Heath, S.K. 2008. Yellow Warbler (Dendroica petechia). Pages 332-339 in W.D. Shuford and T. Gardali, editors, California bird species of special concern: a ranked assessment of species, subspecies, and distinct populations of birds of immediate conservation concern in California. Studies of Western Birds 1. Western Field Ornithologists, Camarillo, CA, and California Department of Fish and Game, Sacramento, CA.

Heath, S.K., AND G. BaLlaRd. 2003. Patterns of breeding songbird diversity and occurrence in riparian habitats of the eastern Sierra Nevada. Pages 21-34 in P.M. Faber, editor, California riparian systems: processes and floodplains management, ecology, and restoration. Riparian Habitat Joint Venture, Sacramento, CA.

Heath, S.K., L.A. Culp, and R. Hirsch-Jacobson. 2006. Remnant black cottonwood riparian forest. Pages 114-115 in T. Gardali and J.D. Lowe, editors, Breeding Bird Census: 2002. Bird Populations 7:114-127.

HeltzeL, J.M., AND S.L. EarNST. 2006. Factors influencing nest success of songbirds in aspen and willow riparian areas in the Great Basin. Condor 108:842-855.

Hensler, G.L., AND J.D. Nichols. 1981. The Mayfield method of estimating nesting success; a model, estimators and simulation results. Wilson Bulletin 93:42-53.

HILL, G.E. 1995. Black-headed Grosbeak (Pheucticus melanocephalus). Issue No. 143 in A. Poole, editor, The Birds of North America Online. Cornell Lab of Ornithology, Ithaca, NY. Available from: http://bna.birds .cornell.edu/bna

Hines, J.E., AND J.R. SAUER. 1989. CONTRAST: a general program for the analysis of several survival or recovery rate estimates. U.S. Geological Survey. Available from: http://www.mbr-pwrc.usgs.gov/software/doc/ contrast.html

Hunt, P.D., and D.J. Flaspohler. 1998. Yellow-rumped Warbler (Dendroica coronata). Issue No. 376 in A. Poole, editor, The Birds of North America Online. Cornell Lab of Ornithology, Ithaca, NY. Available from: http://bna.birds.cornell.edu/bna

Johnson, D.H. 1979. Estimating nest success: the Mayfield method and an alternative. Auk 96:651-661.

Kauffman, J.B., D. Cummings, C. Heider, D. Lythen, and N. OTTING. 2000. Riparian vegetation responses to re-watering and cessation of grazing, Mono Basin, California. Pages 251-256 in P.R. Wellington and R.L. Beschta, editors, Riparian ecology and manage- ment in multi-land use watersheds. American Water Resources Association, Portland, OR.

Knopf, F.I., R.R. Johnson, T. Rich, F.B. SAmson, and R.C. SZARO. 1988. Conservation of riparian ecosystems in the United States. Wilson Bulletin 100:272-284.

Kondolf, G.M., J.W. Webb, M.J. Sale, and T. Felanodo. 1987. Basic hydrological studies for assessing impacts of flow diversions on riparian vegetation: examples from streams of the eastern Sierra Nevada, California, USA. Environmental Management 11:757-769.

Kus, B.E. 1999. Impacts of Brown-headed Cowbird parasitism on productivity of the endangered Least Bell's Vireo. Studies in Avian Biology 18:160-166.

LARIVIÉRE, S. 1999. Reasons why predators cannot be inferred from nest remains. Condor 101:718-721.

LATIF, Q.S. 2009. The influence of predation risk on avian nest habitat selection and the processes underlying nest predation patterns. Doctoral dissertation, University of California, Riverside, CA.

Liebezeit, J.R., AND T.L. George. 2003. Comparisons of mechanically egg-triggered cameras and time-lapse video cameras in identifying predators at Dusky Flycatcher nests. Journal of Field Ornithology 74: 261-269.

LORENZANa, J.C., AND S.G. SEALY. 1999. A meta-analysis of the impact of parasitism by the Brown-headed Cowbird on its hosts. Studies in Avian Biology 18:241-253.

Lowther, P.E. 1993. Brown-headed Cowbird (Molothrus ater). Issue No. 47 in A. Poole, editor, The Birds of North America Online. Cornell Lab of Ornithology, Ithaca, NY. Available from: http://bna.birds.cornell .edu/bna

Manolis, J.C., D.E. Andersen, and F.J. Cuthbert. 2000. Uncertain nest fates in songbird studies and variation in Mayfield estimation. Auk 117:615-626.

MaRTIN, S.G. 2002. Brewer's Blackbird (Euphagus cyanocephalus). Issue No. 616 in A. Poole, editor, The Birds of North America Online. Cornell Lab of Ornithology, Ithaca, NY. Available from: http://bna.birds.cornell .edu/bna

MaRTIN, T.E. 1992. Breeding productivity considerations: what are the appropriate habitat features for management? Pages 455-473 in J.M. Hagan III and D.W. Johnston, editors, Ecology and conservation of neotropical migrant landbirds. Smithsonian Institution Press, Washington and London. 609 pp.

Martin, T.E., AND G.R. GeuPEL. 1993. Nest monitoring plots: methods for locating nests and monitoring success. Journal of Field Ornithology 64:507-519.

MaY, R.M., AND S.K. Robinson. 1985. Population dynamics of avian brood parasitism. American Naturalist 126: 475-494.

MAYFiELD, H.F. 1975. Suggestions for calculating nest success. Wilson Bulletin 87:456-466.

McCreEdy, C., AND S.K. Heath. 2004. Atypical Willow Flycatcher nesting sites in a recovering riparian corridor at Mono Lake, California. Western Birds 35:197-209.

Morton, M.L., K.W. Sockman, And L.E. Peterson. 1993. Nest predation in the Mountain White-crowned Sparrow. Condor 95:72-82.

Nolan, V., Jr., E.D. Ketterson, D.A. Cristol, C.M. Rogers, E.D. Clotfelter, R.C. Titus, S.J. SCHOECH, AND E. SNAJDR. 2002. Dark-eyed Junco (Junco hyemalis). Issue No. 716 in A. Poole, editor, The Birds of North America Online. Cornell Lab of Ornithology, Ithaca, NY. Available from: http://bna.birds.cornell .edu/bna 
Nur, N., S.L. Jones, And G.R. Geupel. 1999. A statistical guide to data analysis of avian monitoring programs. Biological Technical Publication BTP-R6001-1999. USDI Fish and Wildlife Service, Washington, DC.

OHMART, R.D. 1994. The effects of human-induced changes on the avifauna of western riparian habitats. Studies in Avian Biology 15:273-285.

OrtegA, C.P. 1998. Cowbirds and other brood parasites. University of Arizona Press, Tucson, AZ. 371 pp.

PurCELL, K.L. 2006. Abundance and productivity of Warbling Vireo across an elevational gradient in the Sierra Nevada. Condor 108:315-325.

R Development Core Team. 2008. R: a language and environment for statistical computing. R Foundation for Statistical Computing, Vienna, Austria. ISBN 3900051-07-0. Available from: http://www.R-project.org

RobBins, C.S. 1970. Recommendations for an international standard for a mapping method in bird census work. Audubon Field Notes 24:723-726.

Rothstein, S.I., J. Verner, and E. Stevens. 1980. Range expansion and diurnal changes in dispersion of the Brown-headed Cowbirds in the Sierra Nevada. Auk 97:253-267.

. 1984. Radio-tracking confirms a unique diurnal pattern of spatial occurrence in the parasitic Brownheaded Cowbirds. Ecology 65:77-88.

Rothstein, S.I., J. Verner, E. Stevens, And L.V. Ritter. 1987. Behavioral differences among sex and age classes of the Brown-headed Cowbirds and their relation to the efficacy of a control program. Wilson Bulletin 99:322-337.

SAAB, V.A., C.E. Bock, T.D. Rich, And D.S. Dobkin. 1995. Livestock grazing effects in western North America. Pages 311-354 in T.E. Martin and D.M. Finch, editors, Ecology and management of neotropical migratory birds: a synthesis and review of critical issues. Oxford University Press, New York, NY. 489 pp.

SAWYeR, J.O., AND T. KeEler-Wolf. 1995. A manual of California vegetation. California Native Plant Society, Sacramento, CA. 471 pp.

SEDGWICK, J.A. 1993. Dusky Flycatcher (Empidonax oberholseri). Issue No. 78 in A. Poole, editor, The Birds of North America Online. Cornell Lab of Ornithology, Ithaca, NY. Available from: http://bna.birds.cornell .edu/bna
SEdGWICK, J.A., AND W.M. IKo. 1999. Costs of Brownheaded Cowbird parasitism to Willow Flycatchers. Studies in Avian Biology 18:167-181.

Smith, J.I., M.D. Reynolds, And G. LeBuhn. 2005. Warbling Vireo reproductive success and nest-site characteristics in the northern Sierra Nevada, California. Journal of Field Ornithology 76:383-389.

Smith, J.N.M. 1999. The basis for cowbird management: host selection, impacts on hosts, and criteria for taking management action. Studies in Avian Biology 18:104-108

Smith, S.D., A.B. Wellington, J.L. NAChlinger, And C.A. Fox. 1991. Functional responses of riparian vegetation to streamflow diversions in the eastern Sierra Nevada. Ecological Applications 1:89-97.

Stromberg, J.C. and D.T. Patten. 1992. Mortality and age of black cottonwood stands along diverted and undiverted streams in the eastern Sierra Nevada, California. Madroño 39:205-223.

Tewksbury, J.J., S.J. HeJL, And T.E. Martin. 1998. Breeding productivity does not decline with increasing fragmentation in a western landscape. Ecology 79: 2890-2903.

Thompson, F.R., III. 1994. Temporal and spatial patterns of breeding Brown-headed Cowbirds in the Midwestern United States. Auk 111:979-990.

Thompson, F.R., III, And D.E. Burhans. 2003. Video identification of predators at songbird nests in old fields. Auk 116:259-264.

Verner, J., AND L.V. RitTer. 1983. Current status of the Brown-headed Cowbirds in the Sierra National Forest. Auk 100:355-368.

Weckstein, J.D., D.E. Kroodsma, and R.C. Faucett 2002. Fox Sparrow (Passerella iliaca). Issue No. 715 in A. Poole, editor, The Birds of North America Online. Cornell Lab of Ornithology, Ithaca, NY. Available from: http://bna.birds.cornell.edu/bna

Whitfield, M.J., AND M.K. SogGE. 1999. Range-wide impact of Brown-headed Cowbird parasitism on the southwestern Willow Flycatcher (Empidonax traillii extimus). Studies in Avian Biology 18:182-190.

Received 5 July 2009 Accepted 2 February 2010 
APPENDIX. Mean number of territories per year \pm SD and total number of nests found for species observed breeding on North Lake and Rock Creek study plots, eastern Sierra Nevada, California, 2001-2004. Includes species for which we could not map a distinct territory (n/a). Parasitized species are in bold.

\begin{tabular}{|c|c|c|c|c|}
\hline \multirow[b]{2}{*}{ Species } & \multicolumn{2}{|c|}{ North Lake (21 ha) } & \multicolumn{2}{|c|}{ Rock Creek (18 ha) } \\
\hline & $\begin{array}{l}\text { Territories per } \\
\text { year }(\bar{x} \pm S D)\end{array}$ & Nests & $\begin{array}{l}\text { Territories per } \\
\text { year }(\bar{x} \pm \mathrm{SD})\end{array}$ & Nests \\
\hline Green-winged Teal (Anas crecca) & $\mathrm{n} / \mathrm{a}$ & 2 & 0 & - \\
\hline Sooty Grouse (Dendragapus fuliginosus) & 0 & - & $0.6 \pm 0.8$ & 1 \\
\hline Calliope Hummingbird (Stellula calliope) & $1.2 \pm 0.4$ & 2 & $0.4 \pm 0.8$ & 0 \\
\hline Red-breasted Sapsucker (Sphyrapicus ruber) & $1.9 \pm 1.5$ & 3 & $4.3 \pm 2.1$ & 11 \\
\hline Hairy Woodpecker (Picoides villosus) & $0.3 \pm 0.5$ & 0 & $0.6 \pm 0.8$ & 1 \\
\hline Red-shafted Flicker (Colaptes auratus) & $1.5 \pm 0.5$ & 5 & $2.9 \pm 1.2$ & 7 \\
\hline Western Wood-Pewee (Contopus sordidulus) & $6.1 \pm 2.1$ & 21 & $8.2 \pm 3.1$ & 26 \\
\hline Dusky Flycatcher (Empidonax oberholseri) & $15.6 \pm 5.4$ & 48 & $5.5 \pm 1.7$ & 11 \\
\hline Tree Swallow (Tachycineta bicolor) & 0 & - & $\mathrm{n} / \mathrm{a}$ & 1 \\
\hline Violet-green Swallow (Tachycineta thalassina) & $\mathrm{n} / \mathrm{a}$ & - & $\mathrm{n} / \mathrm{a}$ & 16 \\
\hline Steller’s Jay (Cyanocitta stelleri) & 0 & - & $1.9 \pm 0.9$ & 3 \\
\hline Mountain Chickadee (Parus gambeli) & $1.3 \pm 1.5$ & 1 & $2.9 \pm 1.9$ & 5 \\
\hline Bushtit (Psaltriparus minimus) & 0 & - & $0.3 \pm 0.5$ & 1 \\
\hline White-breasted Nuthatch (Sitta carolinensis) & 0 & - & $0.3 \pm 0.5$ & 1 \\
\hline Brown Creeper (Certhia americana) & 0 & - & $1.4 \pm 0.5$ & 4 \\
\hline House Wren (Troglodytes aedon) & $7.6 \pm 1.3$ & 16 & $6.4 \pm 0.8$ & 15 \\
\hline American Dipper (Cinclus mexicanus) & 0 & - & $0.9 \pm 0.6$ & 0 \\
\hline Mountain Bluebird (Sialia currucoides) & $1.7 \pm 1.0$ & 5 & 0 & - \\
\hline American Robin (Turdus migratorius) & $\mathrm{n} / \mathrm{a}$ & 77 & $\mathrm{n} / \mathrm{a}$ & 38 \\
\hline Warbling Vireo (Vireo gilvus) & $7.1 \pm 1.6$ & 18 & $11.9 \pm 1.0$ & 41 \\
\hline Orange-crowned Warbler (Vermivora celata) & 0 & - & $2.8 \pm 0.5$ & 0 \\
\hline Yellow Warbler (Dendroica petechia) & $12.3 \pm 1.5$ & 41 & $3.3 \pm 1.0$ & 10 \\
\hline Yellow-rumped Warbler (Dendroica coronata) & $3.2 \pm 1.5$ & 5 & $4.8 \pm 1.5$ & 5 \\
\hline MacGillivray's Warbler (Oporornis tolmiei) & $0.8 \pm 1.5$ & 1 & $1.8 \pm 1.0$ & 0 \\
\hline Western Tanager (Piranga ludoviciana) & 0 & - & $0.8 \pm 0.5$ & 2 \\
\hline Black-headed Grosbeak (Pheucticus melanocephalus) & 0 & - & $1.0 \pm 1.2$ & 4 \\
\hline Spotted Towhee (Pipilo maculatus) & 0 & - & $0.4 \pm 0.8$ & 0 \\
\hline White-crowned Sparrow (Zonotrichia leucophrys) & $2.5 \pm 1.3$ & 4 & 0 & - \\
\hline Fox Sparrow (Passerella iliaca) & $5.2 \pm 1.6$ & 1 & $7.2 \pm 2.9$ & 4 \\
\hline Song Sparrow (Melospiza melodia) & $5.4 \pm 1.1$ & 17 & $3.0 \pm 0.0$ & 11 \\
\hline Lincoln's Sparrow (Melospiza lincolnii) & $0.3 \pm 0.5$ & 0 & $0.8 \pm 1.5$ & 1 \\
\hline Dark-eyed Junco (Junco hyemalis) & $2.5 \pm 1.3$ & 5 & $7.6 \pm 3.1$ & 16 \\
\hline Red-winged Blackbird (Agelaius phoeniceus) & $\mathrm{n} / \mathrm{a}$ & 17 & 0 & - \\
\hline Brewer's Blackbird (Euphagus cyanocephalus) & $\mathrm{n} / \mathrm{a}$ & 46 & $\mathrm{n} / \mathrm{a}$ & 25 \\
\hline Cassin’s Finch (Carpodacus cassinii) & $4.9 \pm 1.9$ & 12 & $3.3 \pm 1.7$ & 8 \\
\hline Pine Siskin (Carduelis pinus) & $0.3 \pm 0.5$ & 1 & 0 & - \\
\hline TOTAL & $81.4 \pm 6.4$ & 351 & $84.9 \pm 9.1$ & 268 \\
\hline
\end{tabular}

